\title{
Taksifolinin Sıçanlarda Etanolle İndüklenen Oksidatif Beyin Hasarnna Etkisi
}

\section{Effect of Taxifolin on Ethanol-Induced OxidativeBbrain Damage in Rats}

\section{Aslı Özbek Bilgin, Renad Mammadov, Bahadır Süleyman}

Erzincan Üniversitesi Tıp Fakültesi Farmakoloji Anabilim Dalı, Erzincan

Yazışma Adresi / Correspondence:

$$
\text { Aslı Özbek Bilgin }
$$

Erzincan Üniversitesi Tıp Fakültesi Tıbbi Farmakoloji Anabilim Dalı, Erzincan

T: +90505 $3333079 \quad$ E-mail: asliozbekbilgin@gmail.com

Geliş Tarihi / Received : 06.09.2018 Kabul Tarihi / Accepted : 10.09.2018

Öz

Amaç Araştırmalar, alkolun en şiddetli toksik etkisinin merkezi sinir sistemi (MSS) üzerinde olduğunu göstermiştir. Alkolun MSS üzerindeki toksik etkisinin patogenezinde serbest oksijen radikal (SOR) üretiminin artışı, endojen antioksidan üretiminin baskılanması sorumlu tutulmaktadır. Amacımız Taksifolinin sıçanlarda etanolle indüklenen oksidatif beyin hasarına etkisini biyokimyasal olarak araştırmaktır.

( Sakarya Tip Dergisi, 2018, 8(3):638-643 )

Gereç ve Deney hayvanları sağlkkı (SG), tek bașına etanol alan kontrol (EtOH) ve taksifolin +etanol verilen (TEtOH) gruplara ayrıldı. Etanol ve Yöntem Taksifolinin belirlenen sürede verilmesi sonunda hayvanlar yüksek doz anestezi ile öldürülerek beyin dokuları çıkarıldı. Çıkarılan beyin dokularında lipid peroksidasyon ürünü olan malondialdehid (MDA) ve endojen antioksidan olan total glutatyon (tGSH) ölçümleri yapıldı.

Bulgular Etanol verilen hayvan grubunda MDA miktarı sağlıklı ve taksifolin grubuna göre anlamlı yüksek ( $p<0.001)$, tGSH ise anlamlı düşük ( $p<0.001)$ bulundu.

Sonuç Sonuçlarımız, taksifolinin beyin dokusunu etanolun oksidatif hasarına karşı koruduğunu işaret etmektedir.

Anahtar Etanol; taksifolin; beyin hasarı; rat.

Kelimeler

\footnotetext{
Abstract

Objective Studies have shown that alcohol exerts the most severe toxic effect on central nervous system by increasing free oxygen radical production and suppressing endogenous antioxidant production. We aim to biochemically investigate the effect of taxifolin on ethanol-induced oxidative brain damage in rats. ( Sakarya Med J, 2018, 8(3):638-643 ).

Materials and Experimental animals were divided into healthy (SG), ethanol-receiving control (EtOH) and taxifolin+ethanol receiving (TEtOH) groups. At Methods the end of the administration of ethanol and taxifolin, the animals were sacrificed by high dose anesthesia and brain tissues were removed. Malondialdehyde (MDA), lipid peroxidation product, and total glutathione (tGSH), endogenous antioxidant, levels in brain tissues were measured.

Results MDA levels were significantly higher in the rats in the $\mathrm{EtOH}$ group than in those in the TEtOH group ( $p<0.001)$. In contrast, tGSH levels were significantly lower in the rats in the EtOH group than in those in the TEtOH group $(p<0.001)$.
}

Conclusion Our results suggest that taxifolin protects brain tissue from ethanol-induced oxidative damage.

Keywords Ethanol;taxifolin; brain damage; rat 
Sakarya TIp Dergisi 2018;8(3):638-643

\section{Giriş}

Etanol $(\mathrm{CH} 3 \mathrm{CH} 2 \mathrm{OH})$, etil alkol ya da kısaca alkol olarak adlandırılmaktadır. ${ }^{1,2}$ Etil alkol, sanayide kullanılmasına rağmen en çok içki olarak tüketilmektedir. Günlük hayatın getirdiği problemler strese sebep olmakta ve pek cok insan bundan kurtulmak icin alkol almayı tercih etmektedir. ${ }^{3}$ Alkollu kisiler normal kisilere göre daha sık oranda travmalara maruz kalmakta ve ölmektedirler. ${ }^{4}$ Araştırmalar, alkolun en büyük etkisinin merkezi sinir sistemi üzerinde olduğunu göstermiştir. Merkezi sinir sistemi (MSS), alkol ve alkolun indüklediği oksidatif strese karşı en hassas ve savunmasız yapılardan biridir. ${ }^{5}$ Bunun nedeni olarak, yüksek oksijen tüketimi ve sınırlı antioksidan üretimi gösterilmektedir. ${ }^{6,7}$ Alkolun MSS de yol açtığı oksidatif stres patogenezinde serbest oksijen radikal (SOR) üretiminin artışı, endojen antioksidan üretiminin baskılanması sorumlu tutulmaktadır. ${ }^{8}$ Literetür bilgileri, antioksidanların beyin dokusunu alkolun oksidatif hasarından koruyabileceğini düşündürmektedir. Bu çalışmamızda etanol beyin toksisitesine karşı koruyucu etkisini deneyeceğimiz taksifolin (3,5,7,3,4-pentahydroxy flavanone veya dihydroquercetin), turunçgiller ve soğanda bol miktarda bulunan güçlü antioksidan birflavonoiddir. ${ }^{9}$ Flavonoidler, antioksidan aktivitelerini lipid peroksidasyonunu ve serbest radikallerin oluşumundan sorumlu enzimatik reaksiyonları inhibe ederek oluşturdukları belgelenmiştir. ${ }^{10}$ Çeşitli klinik ve in vitro çalışmalar, bu bileşiklerin antioksidan özelliklerinden dolayı nörodejeneratif hastalıkların tedavisinde yararlı olduğunu göstermiştir. ${ }^{11}$ Bu bilgiler, taksifolinin beyin dokusunu, etanol ilişkili oksidatif hasara karşı koruyabileceğini işaret etmektedir. Literetürlerde, taksifolinin etanolle indüklenen beyin hasarına etkisini araştıran bilimsel çalışmalara rastlanmadı. Bu nedenle çalışmamızın amacı, taksifolinin sıçanlarda etanolle indüklenen oksidatif beyin hasarına etkisini biyokimyasal olarak araştırmaktır.

\section{Gereç Ve Yöntemler Hayvanlar}

Çalışmamızda kullanılacak olan 240-255 gram ağırlığındaki 18 adet albino wistar türü erkek sıçanlar Atattürk Üniversitesi Tıbbi Deneysel Uygulama ve Araştırma Merkezinden temin edildi. Hayvanlar ortama adapte olabilmeleri için deneyin yapıldığı ortamda bir hafta boyunca normal oda sıcaklığında (220C) barındırıldı ve beslendi. Çalışmamız randomize kontrollü deneysel bir çalışma olarak tasarlanmıştır. Çalışmanın bütün aşamalarının etik kurallara uygunluğu, "Atatürk Üniversitesi Hayvan Deneyleri Etik Kurulu” tarafından verilen 03.04.2018 tarihli ve 75296309-050.01.04E.1800107389 sayılı yazı ile onaylanmıştır.

\section{Kimyasal maddeler}

Deneyde kullanılan thiopental sodium IE Ulagay-Türkiye, Etanol kendi kliğinimizden, Taksifolin ise Evalar-Rusyadan temin edildi.

\section{Deney grupları}

Deney hayvanları sağlıklı (SG), tek başına etanol alan kontrol (EtOH) ve taksifolin +etanol verilen (TEtOH) gruplara ayrıldı.

\section{Deneyin yapılması}

Hayvanların TEtOH grubuna (n-6) taksifolin $50 \mathrm{mg} / \mathrm{kg}$ dozda oral yoldan gavajla mideye verildi. EtOH (n-6) ve SG (n-6) grubuna ise aynı hacimde çözücü olarak distile su oral uygulandı. Taksifolin ve distile su verildikten 30 dakika sonra TEtOH ve EtOH gruplarına \%50 lik etanol 5 g/kg dozda haftada üç defa toplam 9 doz (21 gün) uygulandı. Taksifolin günde bir defa 21 gün boyunca verildi. 
Bu süre sonunda hayvanlar yüksek doz anestezi ile öldürülerek beyin dokuları çıkarıldı. Çıkarılan beyin dokularında lipid peroksidasyon ürünü olan malondialdehid (MDA) ve endojen antioksidan olan total glutatyon (tGSH) ölçümleri yapıldı. TEtOH ve SG gruplardan elde edilen biyokimyasal sonuçlar EtOH grubundan elde edilen sonuçlarla karşılaştırılarak değerlendirildi.

\section{Biyokimyasal analizler}

\section{Malondialdehid (MDA) ölçümü}

MDA ölçümü MDA'nın sıcak asidik ortamda tiyobarbitürik asitle oluşturduğu rengin 532 nm'de optik dansitesinin ölçülmesi prensibine dayanan Ohkawa ve arkadaş larının metoduna göre yapıldı.12 $25 \mu \mathrm{L}$ örnek üzerine, $25 \mu \mathrm{L}$ sodyum dodesil sülfat $(80 \mathrm{~g} / \mathrm{L}), 1 \mathrm{~mL}$ mix karışım $(200 \mathrm{~g} / \mathrm{L}$ asetik asit $+1.5 \mathrm{~mL} 8 \mathrm{~g} / \mathrm{L} 2$-tiyobarbitürik asit) eklenerek $95^{\circ} \mathrm{C}$ 'de 60 dakika ıstıldı. Soğ utulduktan sonra 4000 devirde 10 dakika santrifü j edildi. Üst tabakanın absorbansı 532 nm’de ölçüldü. Standart olarak 1,1,3,3-tetraetoksipropan kullanılarak çizilen kalibrasyon grafiğinden numunedeki MDA miktarı hesaplandı.

\section{Total glutatyon (tGSH) ölçümü}

tGSH analizi için Sedlak ve ark. göre yapıldı. ${ }^{13}$ Renkli bir bileşik olan 5,5'-dithiobis [2-nitrobenzoic acid] disülfür sülfidril grupları indirgenince sarı renkli bir bileşik oluşur ve bu $412 \mathrm{~nm}$ dalga boyunda ölçülür. Ölçüm için öncelikle deproteinizasyon için tüm örnekler 1:1 oaranında meta fosforik asitle muamele edilip santrifüj edildi. Üst fazdan alınan alınan $50 \mu \mathrm{L}$ süpernatantın üzerine $150 \mu \mathrm{L}$ ölçüm karışımı ( 5.85 mL 100 mM Na-fosfat tamponu, 2.8 mL 1 mM DTNB 3.75 mL 1 mM NADPH, ve $80 \mu \mathrm{L} 625 \mathrm{U} / \mathrm{L}$ Glutathione reductase) eklendi. Glutatyon disülfid ile hazırlanan standart grafiğe göre ölçümler 412 nm'de yapıldı.

\section{İstatistiksel Analizler}

Deney sonuçları "ortalama değer \pm standart hata" $(x \pm$ SEM $)$ olarak ifade edildi. Gruplar arası farkın önemlilik derecesi one-way ANOVA testi kullanılarak belirlendi. Takibinde Fisher's post-hoc Bonferroni yapıldı. Tüm istatistiksel işlemler "IBM SPSS Statistics Version 20" istatistik programında yapıldı ve $p<0.05$ değeri anlamlı olarak kabul edildi.

\section{Bulgular}

\section{MDA Analiz Sonuçları}

Sadece distile su verilen sağıklı hayvan grubunun beyin dokusunda MDA miktarı 4,58 \pm 0,18 $\mu \mathrm{mol} / \mathrm{gr}$ protein olarak ölçüldü. Ancak, etanol uygulanan hayvanların beyin dokusunda MDA miktarının 13,66 $\pm 0,71 \mu \mathrm{mol} / \mathrm{gr}$ proteine yükseldiği saptandı. Taksifolin ise etanolle artan MDA miktarını 5,10 $\pm 0,18 \mu \mathrm{mol} / \mathrm{gr}$ protein düzeyine düşürdü. Deney sonuçları, etanol grubundaki MDA miktarının sağıklı ve taksifolin grubuna göre anlamlı $(p<0.001)$, sağılılı ve taksifolin grubundaki MDA miktar arasındaki farkın ise anlamsız ( $p>0,05)$ olduğunu göstermiştir (Şekil 1, Tablo 1).
Sakarya Tıp Dergisi

2018;8(3):638-643

BiLGiN ve Ark.

Taksifolinin Sı̨̧anlarda Etanolle İndüklenen

Oksidatif Beyin Hasarına Etkisi 


\begin{tabular}{|l|l|l|l|l|l|}
\hline \multicolumn{2}{|l|}{ Tablo 1. MDA düzeyinin ortalama değerleri ve gruplar arası karşılaştırılması } \\
\hline $\begin{array}{l}\text { Deney Grupları } \\
n=6\end{array}$ & Ortalama & Standard Sapma & Ortanca & Min-Max Değer & $\begin{array}{l}\text { p değeri (gruplar } \\
\text { arası anlamlılık } \\
\text { karşılaştırmaları) }\end{array}$ \\
\hline SG & 4.583 & 0.444 & 4.700 & $4.000-5.100$ & $\begin{array}{l}0.000 \\
\text { (SG-EtOH) } \\
1.000 \\
\text { (SG- TEtOH) }\end{array}$ \\
\hline EtOH & 13.666 & 1.751 & 13.500 & $11.000-16.000$ & $\begin{array}{l}0.000 \\
\text { (EtOH-SG) } \\
0.000 \\
\text { (EtOH-TEtOH) }\end{array}$ \\
\hline TEtOH & 5.100 & 0.438 & 5.100 & $4.400-5.600$ & $\begin{array}{l}1.000 \\
\text { (TEtOH-SG) } \\
0.000 \\
\text { (TEtOH- EtOH) }\end{array}$ \\
\hline
\end{tabular}

MDA (Malondialdehid), SG (sağlıklı grup), EtOH(tek başına etanol alan kontrol grubu) ve

TEtOH (taksifolin +etanol verilen)

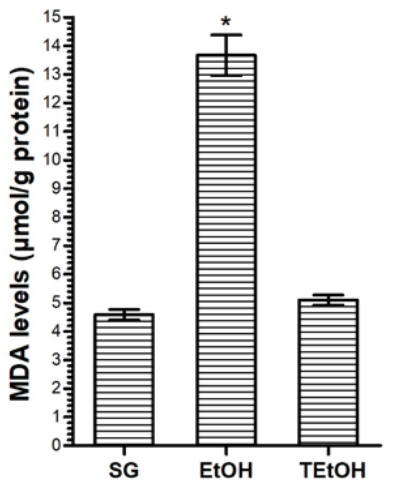

Şekil 1: Taksifolinin beyin dokusu MDA düzeyleri üzerine etkisi ${ }^{*} p<0.001 \mathrm{TEtOH}$ ve SG gruplarına göre MDA (Malondialdehid), SG (sağlıklı grup), EtOH(tek başına etanol alan kontrol grubu) ve TEtOH (taksifolin +etanol verilen)

\section{tGSHanaliz sonuçları}

Sağlıklı hayvanların beyin dokusunda tGSH miktarı 3,52 $\pm 0,15 \mathrm{nmol} / \mathrm{gr}$ protein olarak bulundu. Etanol alan hayvanların beyin dokusunda ise tGSH miktarı azaldı ve 1,10 $\pm 0,06 \mathrm{nmol} / \mathrm{gr}$ protein olarak belirlendi. Taksifolinin ise tGSH düzeyini 3,12 $\pm 0,12 \mathrm{nmol} / \mathrm{gr}$ protein seviyelerinde tutarak etanolle oluşan düşüşü önlediği görüldü. Anlaml.lık derecesi istatistiksel olarak değerlendirildiğinde etanolun tGSH miktarını sağlıklı ve taksifolin grubuna göre anlamlı $(p<0.001)$ artırdığı görülmektedir. Taksifolin ve sağlıklı grubu arasındaki fark ise istatistiksel olarak anlamsız bulundu ( $p>0.05$ ) (Şekil 2, Tablo 2).

\begin{tabular}{|l|l|l|l|l|l|}
\hline \multicolumn{2}{|l|}{ Tablo 2. tGSH düzeyinin ortalama değerleri ve gruplar arası karşılaştırılması } \\
\hline $\begin{array}{l}\text { Deney Grupları } \\
n=6\end{array}$ & Ortalama & Standard Sapma & Ortanca & Min-Max Değer & $\begin{array}{l}\text { P değeri (gruplar } \\
\text { arası anlamlılık } \\
\text { karşıştırmaları) }\end{array}$ \\
\hline SG & 3,516 & 0,360 & 3,500 & $3,00-4,00$ & $\begin{array}{l}0.000 \\
\text { (SG-EtOH) } \\
0.081 \\
\text { (SG- TEtOH) }\end{array}$ \\
\hline EtOH & 1,100 & 0,154 & 1,100 & $0,90-1,30$ & $\begin{array}{l}0.000 \\
\text { (EtOH- SG) } \\
0.000 \\
\text { (EtOH-TEtOH) }\end{array}$ \\
\hline \begin{tabular}{l} 
TEtOH \\
\hline
\end{tabular} & 3,116 & 0,292 & 3,050 & $2,70-3,50$ & $\begin{array}{l}0.081 \\
\text { (TEtOH-SG) } \\
0.000 \\
\text { (TEtOH- EtOH) }\end{array}$ \\
\hline $\begin{array}{l}\text { MDA (Malondialdehid), SG (sağlıklı grup), EtOH(tek başına etanol alan kontrol grubu) ve TEtOH (taksifolin } \\
+ \text { +etanol verilen) }\end{array}$
\end{tabular}




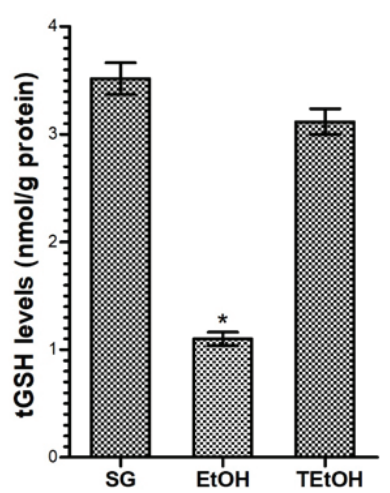

Şekil 2: Taksifolinin beyin dokusu tGSH düzeyleri üzerine etkisi ${ }^{*} p<0.001 \mathrm{TEtOH}$ ve SG gruplarına göre tGSH (Total glutatyon), SG (sağılıkı grup), EtOH (tek başına etanol alan kontrol grubu) ve TEtOH (taksifolin +etanol verilen)

\section{Tartışma}

Bu çalışmada, taksifolinin sıçanlarda etanolle indüklenen oksidatif beyin hasarına etkisi biyokimyasal olarak araştırıldı. Beyin gibi birçok organ ve dokularda oksidatif hasarı değerlendirmede MDA, tGSH ve diğer oksidan antioksidan biyokimyasal parametreler kullanılmaktadır. ${ }^{14}$ Beyin, kalp, akciğer, karaciğer ve barsaklar gibi pek çok organ oksidatif hasarında serbest oksijen radikallerin (SOR) major komponentlerinden biri olduğu gösterilmiştir. ${ }^{15}$ Çok öncelere dayanan araştırmalarda da alkolun beyinde oksidatif stres oluşturduğu bildirilmiştir. ${ }^{16}$ Son zamanlarda yapılan bilimsel çalışmalarda etanolun, potansiyel nörotoksisiteye sahip olduğu ve MSS de oksidatif hasara yol açtı̆̆ belgelenmiş̧tir. ${ }^{17}$ Alkolun oksidatif nörodejeneratif hasarından SOR ların sorumlu olduğu bir başka çalışmada da doğrulanmıştır. ${ }^{18}$ SOR lar arasında en çok bilinenler süperoksit, hidroksil radikali, organik hipoklorit ve nitrik oksit radikalleridir. ${ }^{19}$ Çalışmamızda etanol uygulanan grubun beyin dokusunda MDA miktarının sağlıklı ve taksifolin grubuna göre çok daha anlamlı arttığı görülmüştür. Bilindiği gibi, MDA bir lipid peroksidasyon ürünüdür. Lipid peroksidasyonu hücresel zedelenmenin en önemli nedenlerinden birini oluşturur. ${ }^{20}$ Lipid peroksidasyonu, hücre membranında doymamış yağ asitlerinin SOR'lar tarafından MDA ve ceşitli ürünlere yıkılması reaksiyonudur. ${ }^{21}$ MDA'nın, hücre zarındaki komponentlerin polimerizasyonu ve çapraz bağlanmasına neden olarak iyon transportu, enzimatik aktivite ve intrensik membran özelliklerini değiştirerek hasarın ilerlemesini sağladığı Cross CE ve arkadaşları tarafından rapor edilmiştir. ${ }^{22}$ Taksifolinin etanolla artan MDA düzeyini azaltması, onun lipid peroksidasyonunu ve serbest radikallerin oluşumundan sorumlu reaksiyonları inhibe ettiğini gösteren çalışmalarla uyum içerisinde olduğunu göstermektedir. ${ }^{10}$

Yine bu çalışmamızda, etanol grubu düşük tGSH düzeyi ile sağlıkı ve taksifolin uygulanan gruplardan farklı olmuştur. GSH, birçok hücrede çok yüksek konsantrasyonlarda bulunur ve biyolojik membranları lipid peroksidasyonuna karşı korur. Bu koruma, enzi-mmatik olarak gerçekleşmektedir. ${ }^{23} \mathrm{GSH}$ ayrıca, aynı zamanda hücre içinde tekli oksijen (O2), süperoksit anyonu (.O2-), hidroksi $(\cdot \mathrm{OH})$ radikalleri gibi birçok zararlı oksidanla enzim katalizi olmaksızın da reak $\neg$ siyona girmektedir. ${ }^{24}$ Deney sonuçlarımızla uyum içerisinde olan bir başka çalışmada, etanol verilen hayvanların beyin dokusunda GSH düzeyinin düştüğü ifade edilmiştir. ${ }^{25}$ Taksifolinin, tGSH miktarının etanolle düşmesini önlemesi onun SOR oluşumu üzerindeki inhibitör etkiden kaynaklanmış olabilir. ${ }^{10}$ Ayrıca taksifolinin, GSH ile sinerjik etki oluşturduğu belgelenmiştir. ${ }^{26}$ Sonuç olarak; etanol hayvanların beyin dokusunda oksidan antioksidan dengeyi oksidanların lehine değiştirmiştir. Taksifolin oksidan antioksidan dengenin etanolla oksidanların lehine değişmesini önlemiştir. Bu deney sonuçları takifolinin etanolle indüklenen oksidatif beyin hasarını önlemede yararlı olabileceğini göstermektedir.
Sakarya Tıp Dergisi

$2018 ; 8(3): 638-643$

BiLGiN ve Ark.

Taksifolinin Sı̨̧anlarda Etanolle i̇ndüklenen

Oksidatif Beyin Hasarına Etkis 
1. Stein E. Textbook of clinical chemistry. WB Saunders (eds),.Philadelphia, NW, USA, 1986. pp: 879-886.

2. Vural N. Alifatik Alkoller. Ankara Üniversitesi Eczacılık Fakültesi Yayınları; Toksikoloji. Ankara; 2005. s: 293-305.

3. Palmisano M, Pandey SC. Epigenetic mechanisms of alcoholism and stress-related disorders. Alcohol, 2017, 60: 7-18.

4. Soysal Z, Çakalır C, Gürsel CC. Adli Tıp. 1. baskı. İstanbul Üniversitesi Cerrahpașa Tıp Fakültesi Yayınları; 1999. s: 29-44.

Sakarya TIp Dergisi 2018;8(3):638-643

5. Gonthier B, Signorini Allibe N, Soubeyran A, Eysseric H, Lamarche F, Barret L. Ethanol Can Modify the Effects of Certain Free Radical Generating Systems on Astrocytes. Alcohol Clin Exp Res,2004; 28: 526-534.

6. Wang $X$, Michaelis EK. Selective neuronal vulnerability to oxidative stress in the brain. Front Aging Neurosci 2010; 2: 12.

7. Kim GH, Kim JE, Rhie SJ, Yoon S. The role of oxidative stress in neurodegenerative diseases. Exp Neurobiol 2015; 24: 325-340.

8. Haorah J, Ramirez SH, Floreani N, Gorantla S, Morsey B, Persidsky Y Mechanism of alcohol-induced oxidative stress and neuronal injury. Free Radic Biol Med 2008; 45: 1542-1550.

9. Rice-Evans CA, Miller NJ, Paganga G. Structure-antioxidant activity relationships of flavonoids and phenolic acids. Free Radic Biol Med 1996; 20: 933-956.

10. Cotelle N. Role of flavonoids in oxidative stress. Curr Top Med Chem 2001; 1: 569-590.

11. Bimpilas A, Tsimogiannis D, Balta-Brouma K, Lymperopoulou T, Oreopoulou V. Evolution of phenolic compounds and metal content of wine during alcoholic fermentation and storage. Food Chem 2015; 178: 164-171.

12. Ohkawa H, Ohishi N, Yagi K. Assay for lipid peroxides in animal tissues by thiobarbituric acid reaction. Anal Biochem 1979. 95: 351-358.

13. Sedlak J, Lindsay RH. Estimation of total, protein-bound, and nonprotein sulfhydryl groups in tissue with Ellman's reagent.Anal Biochem 1968; 25: $192-205$

14. Kunak CS, Kukula O, Mutlu E, Genç F, Güleç Peker G, Kuyrukluyıldız U, et al. The effect of etoricoxib on hepatic ischemia-reperfusion injury in rats. Oxid Med Cell Longev 2015, 2015.
15. Kisaoglu A, Borekci B, Yapca OE, Bilen H, Suleyman H. Tissue damage and oxidant/antioxidant balance. Eurasian J Med 2013; 45: 47.

16. Nordmann R. Oxidative stress from alcohol in the brain. Alcohol and Alcoholism 1987:1: 75-82.

17. Wu Y, Li S, Liu J, Liu X, Ruan W, Lu J-W, Liu Y, Lawson T, Shimoni O, Lovejoy D. Stilbenes from Veratrum maackii Regel. Protect against Ethanol-Induced DNA Damage in Mouse Cerebellum and Cerebral Cortex. ACS Chem Neurosci 2018.

18. Crews FT, Nixon K. Mechanisms of neurodegeneration and regeneration in alcoholism. Alcohol \& Alcoholism 2008; 44: 115-127.

19. Büyükuslu N, Yiğitbașı T. Reaktif oksijen türleri ve obezitede oksidatif stres. Marmara Üniversitesi Sağık Bilimleri Enstitüsü Dergisi 2015;5:197203.

20. Repetto M, Semprine J, Boveris A. Lipid peroxidation: chemical mechanism, biological implications and analytical determination. İçinde:Lipid peroxidation, InTech, 2012.

21. Ayala A, Muñoz MF, Argüelles S. Lipid peroxidation: production, metabolism, and signaling mechanisms of malondialdehyde and 4-hydroxy-2 nonenal. Oxid Med Cell Longev 2014; 1-31.

22. Cross CE, Halliwell B, Borish ET, Pryor WA, Ames BN, Saul RL, McCORD JM, Harman D. Oxygen radicals and human disease. Ann Intern Med 1987; 107: 526-545.

23. Di Mascio P, Murphy ME, Sies H. Antioxidant defense systems: the role of carotenoids, tocopherols, and thiols.Am JClin Nutr 1991; 53 194S-200S.

24. Larson RA. The antioxidants of higher plants. Phytochemistry 1988; 27 969-978.

25. Hamid A, Ibrahim FW, Ming TH, Nasrom MN, Eusoff N, Husain K, Latif MA. Zingiber zerumbet L.(Smith) extract alleviates the ethanol-induced brain damage via its antioxidant activity. BMC Complement Altern Med 2018; 18: 101

26. Pereira RB, Sousa C, Costa A, Andrade PB, Valentão P. Glutathione and the antioxidant potential of binary mixtures with flavonoids: synergisms and antagonisms. Molecules 2013; 18: 8858-8872. 